\title{
MEDIUM-TERM IMPACT OF STUMP HARVESTING ON GENERAL SOIL PARAMETERS IN HYLOCOMIOSA SITE TYPE
}

\author{
Zane Lībiete, Arta Bārdule, Ivars Kḷaviṇšs, Zane Kalvīte, Andis Lazdiṇ̌s \\ Latvian State Forest Research Institute 'Silava', Latvia \\ zane.libiete@silava.lv
}

\begin{abstract}
Conifer tree stumps are a prospective source of bioenergy, but there are considerable uncertainties and risks associated with this forestry practice, and environmental consequences of stump harvesting are little studied in the Baltic countries. One of the major concerns is related to the risk of nutrient leaching that may cause pollution of watercourses and decline of tree growth in the next forest generation. The main aim of the present study was to estimate the effect of stump harvesting on general soil and soil solution parameters in three clear-cut areas located in Hylocomiosa site type (dominant tree species prior to clearfelling - Picea abies L. (Karst.)) over a period of 6 years after the stump removal. Two types of treatments were compared: whole-tree harvesting with only above-ground biomass removed (WTH) and whole-tree harvesting combined with the stump removal (WTH+SB). We found no acidification effect of soil and soil solution. Soil C and N stocks six years after harvesting were similar in the plots with and without stump removal, and demonstrated similar pattern of change in both studied treatments (WTH and WTH+SB). Nutrient content and patterns of change varied with the site and year, suggesting that the effects are rather site- than treatment-specific.
\end{abstract}

Key words: Hylocomiosa, stump harvesting, nutrients, soil, soil solution.

\section{Introduction}

Interest in forest bioenergy is growing rapidly on a global and regional scale, and stump harvesting is one of the alternatives to contribute to the transition from a fossil- to a bio-based economy (Berg, 2014). In addition to the production of woodfuel and creating additional revenue for the forest owners, stump extraction improves site preparation conditions and may potentially reduce infection with Heterobasidion (Walmsley \& Godbold, 2010). Although in forest land in boreal and hemiboreal regions a significant amount of carbon is accumulated in the tree root biomass, only a few studies have been done in Latvia on this topic so far (Daugaviete et al., 2008; Bardulis et al., 2017; Liepiņš, Lazdiņš, \& Liepiņš, 2018). There are, however, certain challenges associated with this forestry practice. These include both technical limitations related to large dimensions of stumps or insufficient area for the storage during field drying, as well as climatic and environmental considerations. Warm winters hamper the forwarding of stumps in wet sites, soil organic matter may be removed in the process, and several studies report negative impacts on forest soil carbon stores and greenhouse gas emissions. Increased soil erosion and compaction have been recorded after stump harvesting, as well as depletion of soil nutrient stocks and changes in nutrient cycling. The impacts on future productivity are uncertain, and there is a concern related to the loss of valuable habitat for fungi, mosses, bryophytes and insects. Moreover, uncharacteristic vegetation for forest may develop after the stump harvesting (Berg, 2014; Lazdinš \& von Hofsten, 2009; Walmsley \& Godbold, 2010). The previous findings on the effects of stump lifting are rather controversial; and the impact on environment and biodiversity seems to be largely site- and scale- dependent. It has been found that after stump harvesting nutrient leaching may increase (e.g., Palviainen et al., 2010, Walmsley and Godbold, 2010), but this is not necessarily true in all types of soils (Becker et al., 2016). While several studies conclude that stump harvest negatively affects species richness of understorey plants and reduces moss cover (e.g., Andersson, 2012; Kataja-aho, Fritze, \& Haimi, 2011), Rudolphi \& Strengbom (2016) report no significant long-term effect of this forestry practice on understorey and bryophytes. In Latvia, several studies have been conducted highlighting possible indirect long-term impact of stump harvest (Jansons et al., 2016; Čakšs et al., 2018). The aim of this study was to analyse the changes of general soil parameters six years after stump extraction in three mesotrophic sites in Latvia, comparing two types of treatments - whole-tree harvesting with only above-ground biomass removed and whole-tree harvesting with both above- and below-ground biomass removed.

\section{Materials and Methods}

Description of the study sites

Medium-term changes of general soil and soil solution parameters after biomass and stump harvest in hemiboreal conditions were evaluated in three research sites located in Hylocomiosa site type (dominant tree species before felling - Picea abies L. (Karst.)) in Latvia (Figure 1). Two sampling subplots were established at each research site: control subplot representing whole-tree harvesting, with slash removed (WTH); and treated subplot representing whole-tree harvesting, with both slash and stumps removed $(\mathrm{WTH}+\mathrm{SB})$. Between $\mathrm{WTH}$ and $\mathrm{WTH}+\mathrm{SB}$ sampling subplots a buffer zone was established $(10 \mathrm{~m}$ wide zone where stump and root biomass was removed 


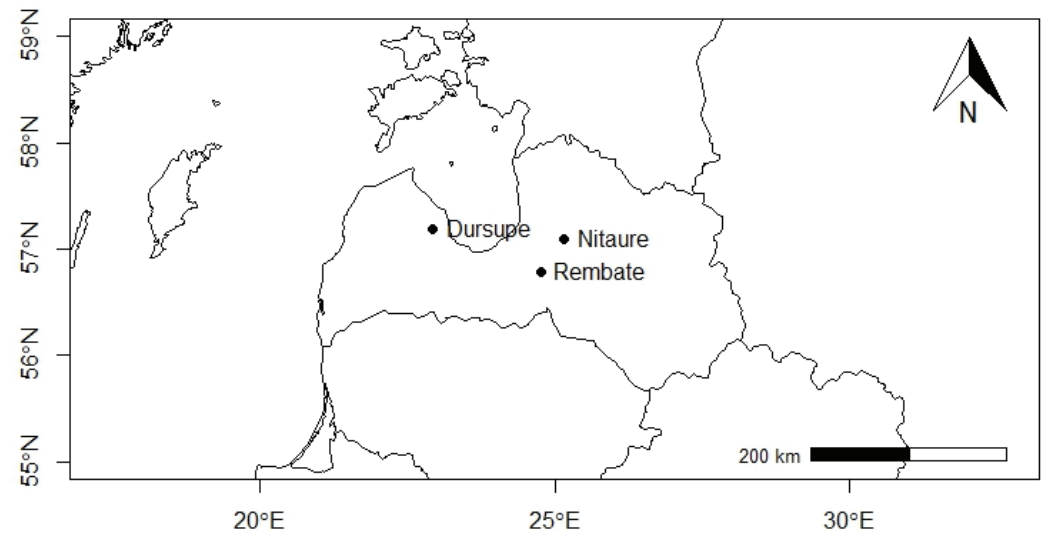

Figure 1. Location of the study sites.

Description of the study sites at the moment of harvesting

Table 1

\begin{tabular}{|c|c|c|c|c|c|}
\hline Site & Location & Soil type (WRB) & Soil texture (FAO) & $\begin{array}{c}\text { Average annual } \\
\text { precipitation } \\
(2011-2018)\end{array}$ & $\begin{array}{c}\text { Mean annual } \\
\text { air temperature } \\
(2011-2018)\end{array}$ \\
\hline Rembate & $\begin{array}{c}\text { Mid-Daugava } \\
\text { Forestry }\end{array}$ & $\begin{array}{c}\text { Folic Albic } \\
\text { Podzols }\end{array}$ & $\begin{array}{c}\text { sand at 0-30 cm; sandy } \\
\text { loam at } 30-45 \mathrm{~cm} \text {; sand at } \\
45-80 \mathrm{~cm} \mathrm{depth}\end{array}$ & $661.6 \mathrm{~mm}$ & $7.5^{\circ} \mathrm{C}$ \\
\hline Dursupe & $\begin{array}{c}\text { Northern Kurzeme } \\
\text { Forestry }\end{array}$ & $\begin{array}{c}\text { Orsteinic Albic } \\
\text { Folic Podzols }\end{array}$ & sand & $562.7 \mathrm{~mm}$ & $7.3^{\circ} \mathrm{C}$ \\
\hline Nìtaure & $\begin{array}{c}\text { Western Vidzeme } \\
\text { Forestry }\end{array}$ & Folic Arenosols & sand & $753 \mathrm{~mm}$ & $7.0^{\circ} \mathrm{C}$ \\
\hline
\end{tabular}

and $10 \mathrm{~m}$ wide zone where stump and root biomass was left). Harvesting was performed in winter 2012 using two types of machinery: CBI stump extraction scoop mounted on a tracked excavator Komatsu PC210LC, and stump extraction scoop MCR-500 prototype constructed in Latvia mounted on a New Holland E215B excavator. In 2013 (3-6 months after harvesting), the harvested stump and root biomass was forwarded to the roadside for storage. After that soil preparation using active disc plough was performed and spruce container seedlings as well as black alder and spruce bare root saplings with improved root system were planted. Description of the study sites is summarized in Table 1.

Soil and soil solution sampling and analyses

In 2011 (one year before the stump harvesting) and in 2018 (six years after the stump harvesting) the soil was sampled in each sample plot at $0-10 \mathrm{~cm}, 10-$ $20 \mathrm{~cm}, 20-40 \mathrm{~cm}$ and $40-80 \mathrm{~cm}$ depth in two sets: for bulk density and soil texture determination (with undisturbed soil sample probes - steel cylinder with a $100 \mathrm{~cm}^{3}$ volume); and for soil chemical analysis (with Dutch soil sampler probe). Soil samples were prepared and analyzed in the Forest environment laboratory of the Latvian State Forest Research Institute 'Silava' (LSFRI Silava) according to the standard methods approved by the ICP forest monitoring programme. Samples were prepared for analysis according to the LVS ISO 11464 (2005) standard. Fine earth fraction of soil (D $<2 \mathrm{~mm}$ ) was used for soil chemical analysis and following parameters were determined: bulk density according to LVS ISO 11272:2017; total C content using elementary analysis according to LVS ISO 10694:2006; carbonate content using Eijkelkamp calcimeter according to LVS ISO 10693:2014, total nitrogen content using modified Kjeldahl method according to LVS ISO 11261:2002 $\mathrm{L}$; soil $\mathrm{pH}$ in $0.01 \mathrm{M} \mathrm{CaCl}_{2}$ solution according to LVS ISO 10390:2006; phosphorus and potassium content in soil was determined in concentrated $\mathrm{HNO}_{3}$ extract according to LVS EN 14672:2006 and LVS ISO 99643:2000, respectively.

In all research sites, soil solution was sampled with suction tube lysimeters (Eijkelkamp), with soil solution sampler cups, made of porous ceramic ( $92 \%$ pure $\mathrm{Al}_{2} \mathrm{O}_{3}$ ), and a body of trace metal-free PVC installed vertically into the soil. Five pairs of suction tube lysimeters at 2 depths (30 and $60 \mathrm{~cm}$ ) per sample plot (both in the control subplot and treated subplot) were installed in spring 2014. Soil solution was collected twice per month during the vegetation season in 2014 and 2015 and once per month in 2016, 2017 and 2018. The soil solution samples were analyzed in the Forest Environment Laboratory of LSFRI Silava. Nitrate nitrogen $\left(\mathrm{NO}_{3}^{-}-\mathrm{N}\right)$ concentration in water samples was 
determined using FORMACSHT TOC/TN Analyzer (ND25 nitrogen detector), phosphate-phosphorus $\left(\mathrm{PO}_{4}^{3-}-\mathrm{P}\right)$ was determined using an ammonium molybdate spectrometric method according to ISO 6878 , potassium was determined using a flame emission spectrometric method according to ISO 9964-3:2000, $\mathrm{pH}$ was determined according to LVS ISO 10523:2012 and conductivity was determined according to LVS EN 27888:1993. Before chemical analysis, the water samples were filtered using borosilicate glass fiber filters without a binder.

\section{Statistical analyses}

Data processing and all statistical analyses were performed in $R$ (R Core Team 2017). For all research sites, the data of soil and soil solution general parameters in treated plots $(\mathrm{WTH}+\mathrm{SB})$ were compared to the control plots of the sites (WTH). Statistical differences between the harvested and control plots were analyzed with the Wilcoxon rank sum test with continuity corrections.

\section{Results and Discussion}

\section{Soil condition}

Soil compaction, which is one of the possible consequences of stump lifting and may further negatively influence water infiltration and nutrient availability, generally was not observed in our study sites. Stump removal increased soil bulk density over pre-harvest measurements only at the $0-10 \mathrm{~cm}$ depth in Rembate, but in Dursupe and Nitaure, in the surface soil $(0-10$ $\mathrm{cm}$ ), stump removal decreased the bulk density due to soil mixing that takes place during stump extraction (Table 2). According to previous studies, stump removal may increase soil bulk density, but in general, these effects appear to be short-term and are less severe as the impacts of repeated passes of forwarders during harvesting (Walmsley \& Godbold, 2010). In British Columbia, Hope (2007) found that in the first year after harvesting, mineral soil bulk density was greater in all stump-removal treatments compared to the control, but 10 years after the treatment, bulk densities had decreased and no treatment effects were displayed.

Despite the lack of specific research of how stump harvesting influences soil acidification, some previous studies suggest that intensive stump removal should be avoided in sites sensitive to acidification and may intensify the acidification process also in other areas (Walmsley \& Godbold, 2010). Our study did not reveal any soil acidification effects of stump harvesting after six years (Figure 2). Similar results were obtained by Hope (2007) who recorded no $\mathrm{pH}$ changes in either the forest floor or mineral soil horizon 10 years after the stump harvesting. Staaf \& Olsson (1994) concluded that acidification effects in a Norway spruce (Picea abies (L) Karst) forest in southwest Sweden are the greatest over the short term, with soil solution $\mathrm{pH}$ returning to pre-treatment levels after 5 years. In contrast, Hyvönen et al. (2016) found slightly higher soil $\mathrm{pH}$ after the stump harvesting in Norway spruce stands in Central Finland.

Several studies have expressed concern that enhanced mineralization rates following the soil disturbance during stump harvesting may deplete the pool of nutrients in the soil and cause soil carbon losses (e.g., Reynolds, 2007; Staaf \& Olsson, 1994). The effect of stump harvest on soil $\mathrm{C}$ and $\mathrm{N}$ pools is caused by the direct loss of $\mathrm{C}$ and $\mathrm{N}$ with harvested stump biomass, the altered soil organic matter decomposition rate due to soil disturbance and decreased litter production of the new stand (Jurevics et al., 2016). The results obtained in our study show similar trends both in all treated plots $(\mathrm{WTH}+\mathrm{SB})$ and in all control plots (WTH). The total organic $\mathrm{C}$ stock in soil $(0-80 \mathrm{~cm}$ depth) in 2018 was lower, but the total $\mathrm{N}$ stock in soil (0-80 cm depth) was higher, if compared with respective values prior to harvesting in 2011. Thus, no significant effect of stump harvesting treatment on the total organic $\mathrm{C}$ or $\mathrm{N}$ stock in soil was detected, if compared to the whole-tree harvesting practice. Hyvönen et al. (2016) reported similar results describing

Table 2

Summary of impact of stump removal on soil bulk density $\left(\mathrm{kg} \mathrm{m}^{3}\right)$ in soil upper layers

\begin{tabular}{|c|c|c|c|c|}
\hline \multirow{2}{*}{ Study site } & \multirow{3}{*}{ Treatment } & \multicolumn{3}{c|}{ Soil layer } \\
\cline { 3 - 5 } & & $0-10 \mathrm{~cm}$ & $10-20 \mathrm{~cm}$ & $20-40 \mathrm{~cm}$ \\
\hline \multirow{4}{*}{ Rembate } & one year before treatment (WTH, 2011) & 800.5 & 1354.5 & 1603.6 \\
\cline { 2 - 5 } & six years after treatment (WTH+SB, 2018) & 1224.3 & 1020.1 & 1443.1 \\
\cline { 2 - 5 } & control (WTH, 2018) & 847.9 & 1394.5 & 1298.5 \\
\hline \multirow{4}{*}{ Dursupe } & one year before treatment (WTH, 2011) & 1578.4 & 1676.0 & 1625.1 \\
\cline { 2 - 5 } & six years after treatment (WTH+SB, 2018) & 1352.6 & 1517.3 & 1511.0 \\
\cline { 2 - 5 } & control (WTH, 2018) & 1510.4 & 1473.7 & 1588.5 \\
\hline \multirow{3}{*}{ Nitaure } & one year before treatment (WTH, 2011) & 1567.0 & 1626.9 & 1665.5 \\
\cline { 2 - 5 } & six years after treatment (WTH+SB, 2018) & 1312.2 & 1540.4 & 1545.8 \\
\cline { 2 - 5 } & control (WTH, 2018) & 1572.3 & 1505.4 & 1563.0 \\
\hline
\end{tabular}




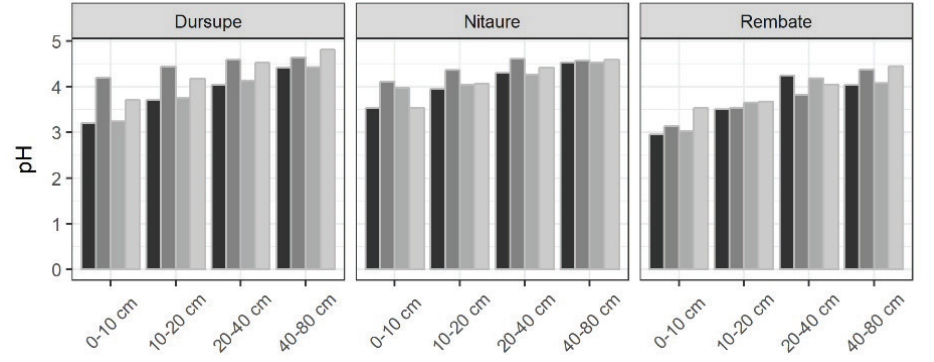

Figure 2. Impact of stump removal on soil $\mathrm{pH}_{\mathrm{CaCl} 2}$.
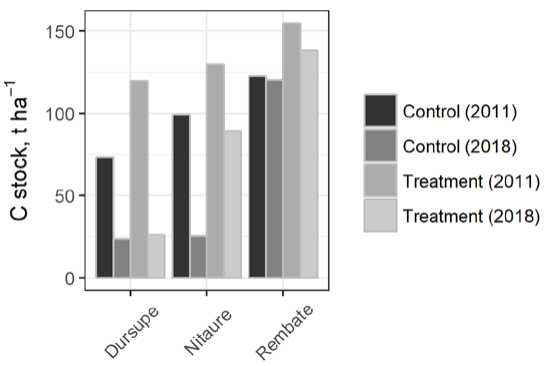

Control (2011)

Control (2018)

Treatment (2011)

Treatment (2018)

Figure 3. Impact of stump removal on carbon and nitrogen stock in soil $(0-80 \mathrm{~cm}$ depth).

no significant treatment effect on the soil $\mathrm{C}$ and $\mathrm{N}$ pools after stump harvesting. Strömgren et al. (2012) also report small or absent effect of stump harvesting on $\mathrm{CO}_{2}$ flux or soil decomposition processes during the first years after the stump harvesting compared to site preparation such as mounding. Karlsson \& Tamminen (2013) found that $\mathrm{C}$ and $\mathrm{N}$ concentrations in the soil tended to be lower after stump harvesting, whereas the total $\mathrm{C}$ and $\mathrm{N}$ pools were not affected. Several studies suggest that the effect of stump removal on soil C and $\mathrm{N}$ pools is low, compared to the effect of slash removal (Egnell, 2016; Jurevics et al., 2016), as nutrient concentrations in slash are higher than in stumps and coarse roots (Iwald et al., 2013).

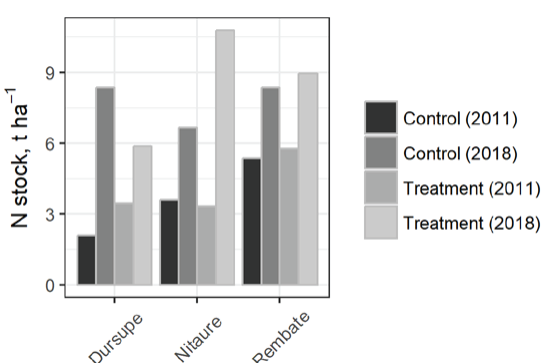

The buffering capacity of the soil is directly linked to the nutrient availability, and removal of base cations through harvesting therefore reduces the soil buffering capacity that may result in an increased acidification of soil and water. Second to N, P is the most important nutrient for the next forest generation. Results of our study do not reveal any decrease in $\mathrm{P}$ or base cation concentrations in the soil after stump harvesting; on the contrary, we observed a slight increase of $\mathrm{P}$ and $\mathrm{K}$ content in the soil (Figure 4), possibly related to the mineralization of fine slash and lower consumption of nutrients by the new forest generation, as the need for nutrients in conifers is relatively low during the first
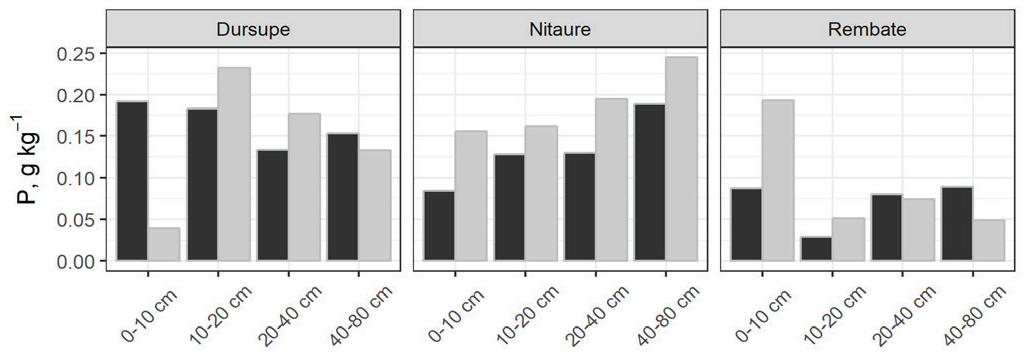

Control (2018)

Treated (2018)
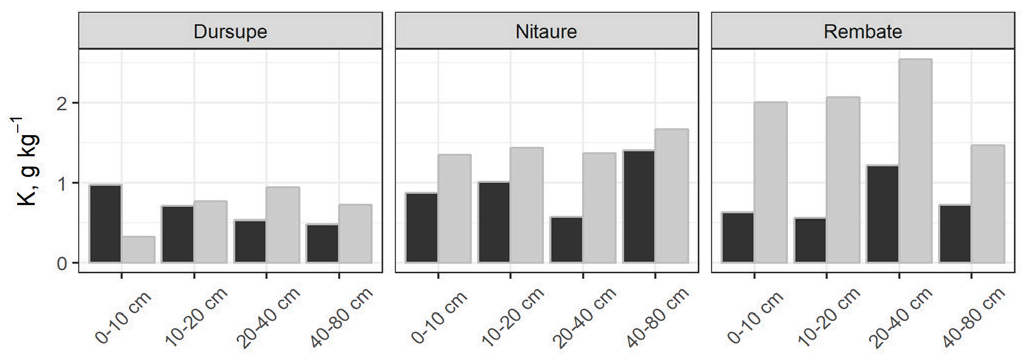

Control (2018)

Treated (2018)

Figure 4. Impact of stump removal on phosphorus and potassium content in soil. 
decades after stand establishment (Helmisaari et al., 2002). According to Hellsten et al. (2013), pine and spruce stumps have very low nutrient concentrations if compared, for example, with foliage or branches, as previously reported by Palviainen et al. (2004). The review performed by Ranius et al. (2018) highlights a more pronounced negative effect of stump harvesting on base cations than on phosphorus or nitrogen.

\section{Soil solution}

Some authors have recorded an increased nutrient, especially phosphorus (P), leaching following the stump harvesting (Palviainen et al., 2010; Walmsley \& Godbold, 2010), which can be considered a serious environmental risk (Becker et al., 2016). In contrast to the expected acidification, we found no effect at all (Nitaure, Rembate) or detected even significantly $(\mathrm{p}<0.05)$ higher $\mathrm{pH}$ values in the treated plot (WTH+SB) compared to the control plot (WTH) in 2014-2016 in Dursupe (Figure 5).

Other parameters, however, showed a different pattern. Conductivity is directly related to the concentration of ions (dissolved salts) in the water.
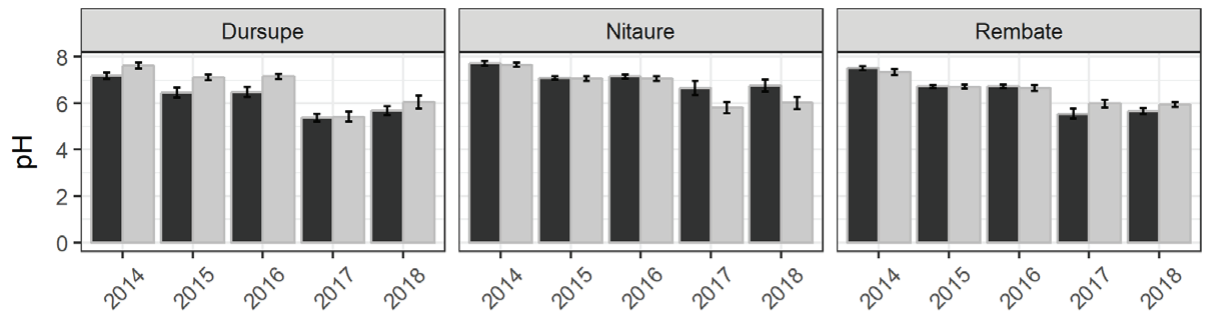

Control
Treated
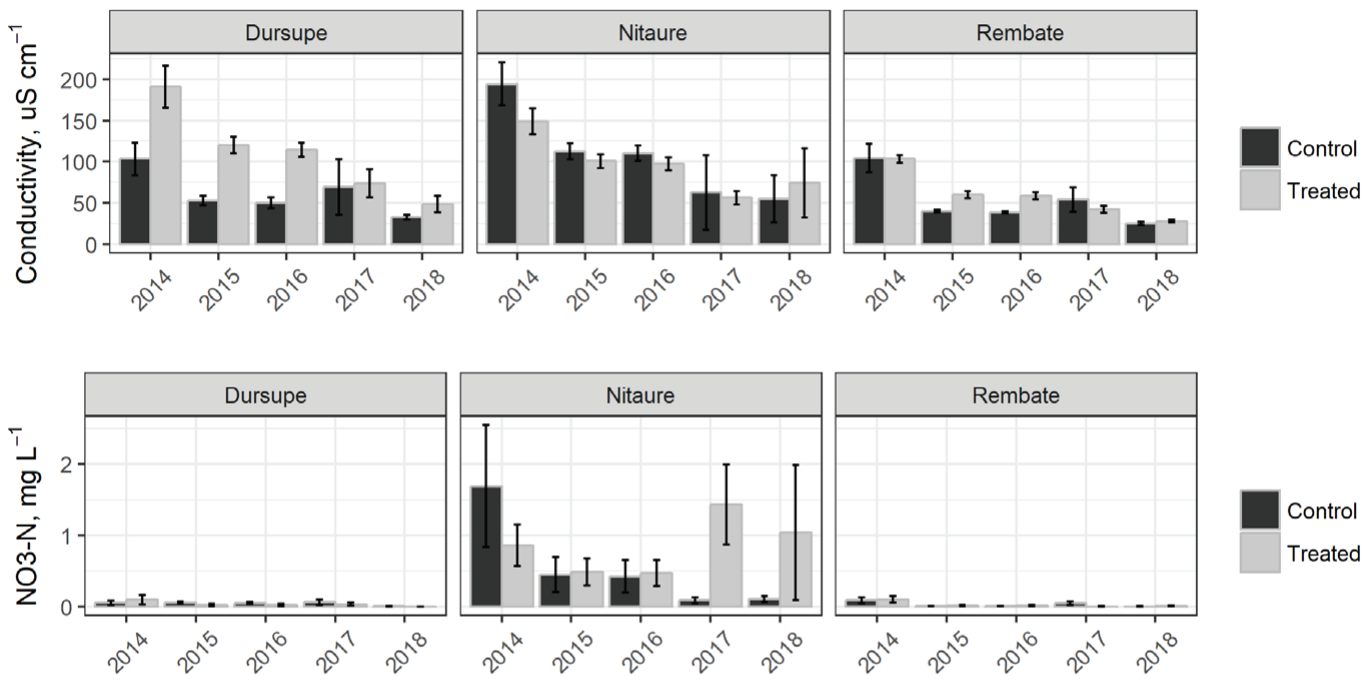

Control

Treated
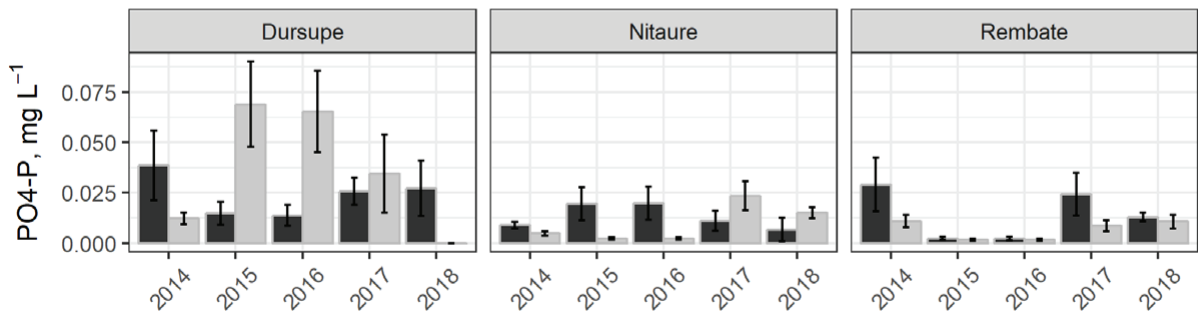

Control

Treated
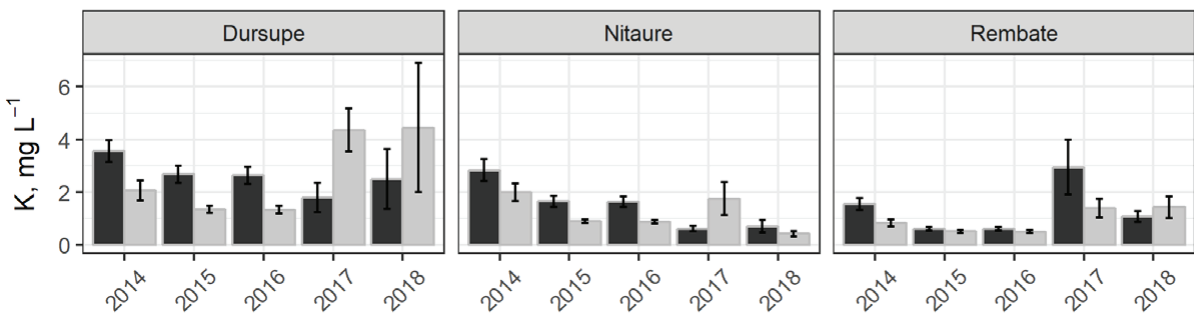

Control

Treated

Figure 5. Impact of stump removal on general soil solution parameters and nutrient content. 
Compared to the control plots (WTH), a significantly $(p<0.05)$ higher soil solution conductivity in the treated plot (WTH+SB) was found in 2014-2016 in Dursupe and in 2015-2016 in Rembate, indicating a potentially increased leaching of salts in the treated plots. A similar effect was not observed in Nitaure. Nutrient content in soil solution for the different harvest treatments showed an irregular pattern. $\mathrm{NO}_{3}^{-}-\mathrm{N}$ concentration in soil solution significantly peaked only in the treated plot $(\mathrm{WTH}+\mathrm{SB})$ in Nitaure in 2017, while $\mathrm{PO}_{4}^{3-}-\mathrm{P}$ concentration in soil solution significantly peaked only in the treated plot (WTH+SB) in Dursupe in 2015-2016. In contrast, $\mathrm{K}$ concentration in soil solution significantly peaked only in the control plot (WTH) in all study sites - in Dursupe in 2014-2016, in Nitaure in 2015-2016, but in Rembate in 2014. Other studies indicate that the forest site type, i.e. the soil, has a more pronounced effect on the annual nutrient leaching than soil disturbance caused by stump harvesting (Becker et al., 2016).

\section{Conclusions}

1. The results of the study of nutrient content in the soil in three mesotrophic sites, where stump harvesting was performed in 2012, revealed no acidification effect of soil and soil solution.

2. Soil $\mathrm{C}$ and $\mathrm{N}$ stocks six years after harvesting were similar in the plots with and without stump removal, and demonstrated a similar pattern of change in both studied treatments (WTH and $\mathrm{WTH}+\mathrm{SB}$ ).

3. Nutrient content and patterns of its change varied with the site and year, suggesting that the effects are rather site- than treatment-specific.

\section{Acknowledgements}

The study was carried out within the framework of Latvian State Forest Research Institute 'Silava' and JSC 'Latvia's State Forests' collaboration research programme 'The impact of forest management on ecosystem services provided by forests and related ecosystems'.

\section{References}

1. Andersson, J. (2012). Long and short term effects of stump harvesting on saproxylic beetles and ground flora. Doctoral thesis, Acta Universitatis Agriculturae Sueciae 2012:99, Umeå.

2. Bardulis, A., Jansons, A., Bardule, A., Zeps, M., \& Lazdins, A. (2017). Assessment of carbon content in root biomass in Scots pine and silver birch young stands of Latvia. Baltic Forestry 23(2), 482-489.

3. Becker, H, Aosaar, J., Varik, M., Morozov, G., Kanal, A., \& Uri, V. (2016). The effect of Norway spruce stump harvesting on net nitrogen mineralization and nutrient leaching. Forest Ecology and Management 377, 150160. DOI: 10.1016/j.foreco.2016.07.005.

4. Berg, S. (2014). Technology and systems for stump harvesting with low ground disturbance. Doctoral Thesis, Swedish University of Agricultural Sciences, Umeå, Sweden.

5. Čakšs, R., Robalte, L., Desaine, I., Džeriņa, B., \& Jansons, A. (2018). Ground vegetation composition and diversity in drained Norway spruce (Picea abies (L.) Karst.) stands 50 years after whole-tree harvesting management: case study in Latvia. Forestry Studies | Metsanduslikud Uurimused 69, 33-43. DOI: 10.2478/ fsmu-2018-0010.

6. Daugaviete, M., Gaitnieks, T., Kḷaviņa, D., \& Teliševa, G. (2008). Oglekḷa akumulācija virszemes un sakņu biomasā priedes, egles un bērza stādījumos laiksaimniecības zemēs (Carbon accumulation in the above-ground and root biomass of pine, birch and spruce cultivated in agricultural soils). Mežzinātne 18: 35-52. (in Latvian)

7. Egnell, G. (2016). Effects of slash and stump harvesting after final felling on stand and site productivity in Scots pine and Norway spruce. Forest Ecology and Management 371, 42-49. DOI: 10.1016/j.foreco.2016.03.006.

8. Hellsten, S., Helmisaari, H.-S., Melin, Y., Skovsgaard, J.P., Kaakinen, S., Kukkola, M., Saarsalmi, A., Petersson, H., Akselsson, C. (2013). Nutrient concentrations in stumps and coarse roots of Norway spruce, Scots pine and silver birch in Sweden, Finland and Denmark. Forest Ecology and Management 290, 40-48. DOI: 10.1016/j. foreco.2012.09.017.

9. Helmisaari, H., Makkonen, K., Kellomäki, S., Valtonen, E., \& Mälkönen, E. (2002). Below- and above-ground biomass, production and nitrogen use in Scots pine stands in eastern Finland. Forest Ecology and Management 165, 317-326. DOI: 10.1016/S0378-1127(01)00648-X.

10. Hope, G.D. (2007). Changes in soil properties, tree growth, and nutrition over a period of 10 years after stump removal and scarification on moderately coarse soils in interior British Columbia. For. Ecol. Manage. 242 2/3, 625-635. DOI: 10.1016/j.foreco.2007.01.072.

11. Hyvönen, R., Kaarakka, L., Leppälammi-Kujansuu, J., Olsson, B.A., Palviainen, M., Vegerfors-Persson, B., \& Helmisaari, H.S. (2016). Effects of stump harvesting on soil $\mathrm{C}$ and $\mathrm{N}$ stocks and vegetation 8-13 years after clear-cutting. Forest Ecology and Management 371, 23-32. DOI: 10.1016/j.foreco.2016.02.002.

12. Iwald, J., Löfgren, S., Stendahl, J., \& Karltun, E. (2013). Acidifying effect of removal of tree stumps and logging residues as compared to atmospheric deposition. Forest Ecology and Management 290, 49-58. DOI: 10.1016/j. foreco.2012.06.022. 
13. Jansons, Ā., Robalte, L., Čakšs, R., \& Matisons, R. (2016). Long-term effect of whole tree biomass harvesting on ground cover vegetation in a dry Scots pine stand. Silva Fennica 50(5), article ID 1661. DOI: 10.14214/ sf.1661.

14. Jurevics, A., Peichl, M., Olsson, B.A., Strömgren, M., \& Egnell, G. (2016). Slash and stump harvest have no general impact on soil and tree biomass C pools after 32-39 years. Forest Ecology and Management 371, 33-41. DOI: $10.1016 /$ j.foreco.2016.01.008.

15. Karlsson, K., \& Tamminen, P. (2013). Long-term effects of stump harvesting on soil properties and tree growth in Scots pine and Norway spruce stands. Scand. J. For. Res. 28, 550-558. DOI: 10.1080/02827581.2013.805808.

16. Kataja-aho, S., Fritze, H., \& Haimi, J. (2011). Short-term responses of soil decomposer and plant communities to stump harvesting in boreal forests. Forest Ecology and Management 348, 153-163. DOI: 10.1016/j. foreco.2011.04.002.

17. Lazdinš, A., \& von Hofsten, H. (2009). Technical and environmental issues of stump harvesting for biofuel production in Latvia. In Research for Rural Development 2009, 20-22 May 2009 (pp. 155-162). Latvia University of Agriculture, Jelgava, Latvia.

18. Liepiņš, J., Lazdiņ̌s, A., \& Liepiņšs, K. (2018). Equations for estimating above- and belowground biomass of Norway spruce, Scots pine, birch spp. and European aspen in Latvia. Scandinavian Journal of Forest Research 33(1), 58-70. DOI: 10.1080/02827581.2017.1337923.

19. Palviainen, M., Finér, L., Kurka, A.-M., Mannerkoski, H., Piirainen, S., \& Starr, M. (2004). Decomposition and nutrient release from logging residues after clear-cutting of mixed boreal forest. Plant and Soil 263, 53-67. DOI: 10.1023/B:PLSO.0000047718.34805.fb.

20. Palviainen, M., Finer, L., Laiho, R., Shorohova, E., Kapitsa, E., \& Majamaa, I.V. (2010). Phosphorus and base cations accumulation and release patterns in decomposing Scots pine, Norway spruce and silver birch stumps. For. Ecol. Manage. 260, 1478-1489. DOI: 10.1016/j.foreco.2010.07.046.

21. Ranius, T., Hamalainen A., Egnell, G., Olsson, B., Eklof, K., Stendahl, J., Rudolphi, J., Stens, A., \& Felton, A. (2018). The effects of logging residue extraction for energy on ecosystem services and biodiversity: A synthesis. Journal of Environmental Management 209, 409-425. DOI: 10.1016/j.jenvman.2017.12.048.

22. Reynolds, B. (2007). Implications of changing from grazed or semi-natural vegetation to forestry for carbon stores and fluxes in upland organo-mineral soils in the UK. Hydrology and Earth System Sciences 11, 61-76.

23. Rudolphi, J., \& Strengbom, J. (2016). No support for long-term effects of commercial stump harvest on understorey vegetation. Forest Ecology and Management 371, 84-89. DOI: 10.1016/j.foreco.2016.01.039.

24. Staaf, H., \& Olsson, B.A. (1994). Effects of slash removal and stump harvesting on soil-water chemistry in a clearcutting in South-West Sweden. Scand. J. For. Res. 9, 305-310. DOI: 10.1080/02827589409382844.

25. Strömgren, M., Mjöfors, K., Holmström, B., \& Grelle, A. (2012). Soil CO flux during the first years after stump harvest in two Swedish forests. Silva Fennica 46, 67-79. DOI: 10.14214/sf.66.

26. Walmsley, J.D., \& Godbold, D.L. (2010). Stump harvesting for bioenergy - A review of the environmental impacts. Forestry: An International Journal of Forest Research 83(1), 17-38. DOI: 10.1093/forestry/cpp028. 